\title{
The role of sports activity in the aggressive behavior level of primary school pupils
}

* Hadeer Emad Al-Din Nofal Ahmad

** sekena Mohamed Nasr

\section{${ }^{* * *}$ Ahmed Mohamed Abdel Moneim Allam}

Introduction and research problem:

The phenomenon of aggression is widespread among males and females in the primary stage. Perhaps one of the most important reasons behind violence and aggressive behavior is the roots of society and patriarchal power. The most important social institutions, as they are the link between the individual and society, as it is considered the main tool for the process of socialization.

(Sami Zidan 2000: 1) Also, proper family upbringing means creating an appropriate climate within the family to grow up healthy and body and meet their basic needs and provide opportunities for them to interact with their community in a positive and sound interaction (Hassan Mustafa 2004: 119) and that children who grow up in homes with Aggression and physical ill-treatment, and some forms of antisocial behavior, deal in school in the same way. Rather than treating these children as trouble-makers and trouble-makers, it is better to understand the roots of the problem and help them to

Dealing with their anger in an appropriate manner (Nichtos, Mary 2002: 58)

This is the phenomenon of violence in general is one of the most phenomena that requires attention on the part of the family and society to modify the behavior of individuals, and not only this, but there has been development in how violence is, but in the methods used by students in implementing aggressive behavior where we conclude that the behavior

Aggression is associated with individual deficiencies inherent in the biological structure of the individual, and are embodied in imbalances.

Physical, psychological and mental, and it explodes in the light of aggressive anti-social behavior, violent appears in various forms of social deviations that may be known and limited and may be hidden and preferred by law and dropped by statistics (Ahmed Abdel-Jawad 2006: 49)

* Researcher at the doctorate level, Department of Fundamentals of Physical Education, Faculty of Physical Education for Boys, University of Alexandria

** Professor of Sports Psychology, Department of Fundamentals of Physical Education, Faculty of Physical Education, Alexandria University.

*** Assistant Professor, Department of Fundamentals of Physical Education, Faculty of Physical Education for Boys, Alexandria University. 
In view of the increasing phenomenon of violence within educational institutions, which calls for attention to the fact that the violence practiced by students in the elementary stage and sometimes some teachers and administrators show aggressive behaviors towards their students, and if some objective reasons leading to this phenomenon increase in society and in the vicinity of institutions Educational which drives us.

To study this phenomenon in educational institutions because it constitutes the constructive relationship between a student and professors as the educational process is based on permanent and reciprocal interaction between students if we know that one behavior affects the other as the school is the source of all aggressive stresses and behaviors, and sports activity is the only outlet For these pupils who practice aggressive behavior, where exercise leads to a decrease or limit of aggressive behavior,

Play is an important therapeutic tool with children with mental disorders, as the child merges with his toys and playing tools and responds to his symbols and meanings, and playing for him is a fact that he lives with his reality and imagination and the play may be calm or violent and may include exploration or aggression or a side of sexual behavior and may be individual or Collectively, the child through play can express his emotions and tensions, as many desires and needs that are satisfactorily satisfied with him can receive satisfaction in playing practice, and the child needs to empty his pent-up desires, aggressive tendencies and internal struggles, and this is usually done during playing.

(Totem Karima 2015 on Sawalha 2004: 199)

Hence the importance of the research to show the role of sports activity in reducing or reducing violence among primary school students and reducing violence within the school walls.

\section{Research objective:}

This research aims to:Learn about the role of sports activity in reducing the level of aggressive behavior for primary school students.

\section{Research hypotheses :}

1 / There are statistically significant differences in the degree of aggression towards the self among

2 / There are statistically significant differences in the degree of aggression towards others among students practicing sports activity and not practicing for the benefit of practitioners.

3 / We find statistically significant differences in the degree of aggression towards property between students practicing sports activity and those not practicing in favor of practitioners.

4 / There are statistically significant differences in the level of aggressive behavior among students practicing sports activity and not practicing for the benefit of practitioners.students practicing sports activity and not practicing for the benefit of practitioners.

\section{Research fields:}

\section{1/ The human field:}

Primary school pupils in East Alexandria schools for the academic year 2019/2020 


\section{2 / Time domain:}

The first semester of the academic year 2019/2020

Search terms:The research mentioned terms that require the researcher to clarify it as follows: sport activities:

This is the process that is done regularly when practicing various sports outside school hours, which allows the achievement of physical, social and cognitive goals that achieve physical and mental integrity.

\section{Agressive behavior :}

It is that behavior that seeks to cause harm to oneself or others or property and causes anxiety and the desire to harm in compensation for deprivation and is considered to be any deliberate behavior aimed at offending others or to the self by using the word or action which leads to physical, psychological or material harm (Ibrahim Attia 2002: 20)

\section{Research Methodology :}

Given the nature of the research topic and the problem related to aggression among primary school students, the researcher adopted the descriptive approach to its suitability for this study.

\section{The research sample:}

A sample of primary school pupils was chosen from several schools of East Alexandria from practitioners for sports activities outside of school, consisting of 100 pupils and other non-practitioners, consisting of 100 pupils, as the sample should be part of the study community from which field data is collected and is considered part of Everyone in the sense that a group of community members is taken to be a representative of the research community (Rasheed Zerawati 2007: 234).

\section{Search tool:}

The researcher used the aggressive behavior scale of Hassan Nassar in (2017) and the scale is 3 axes (aggressive behavior towards the self, aggressive behavior towards others, aggressive behavior towards properties) and it consists of 40 words and a five-year rating scale and a total score of 200 degrees as the description depends on the study, analysis and interpretation The phenomenon by specifying its characteristics and dimensions and employing the relationship between them with the aim of arriving at an integrated scientific description where the questionnaire was used as a tool to obtain facts, data and information in the shortest possible time (Hassan Al-Shafi'i, Susan Morsi 2002 AD: 203-205) where the test was of high credibility with the meaning of the test of truth ( Fatima Awad, Mervat Khafaga, 2002: 167). 
Table (1)

Table of equivalence of the research sample in the basic variables.

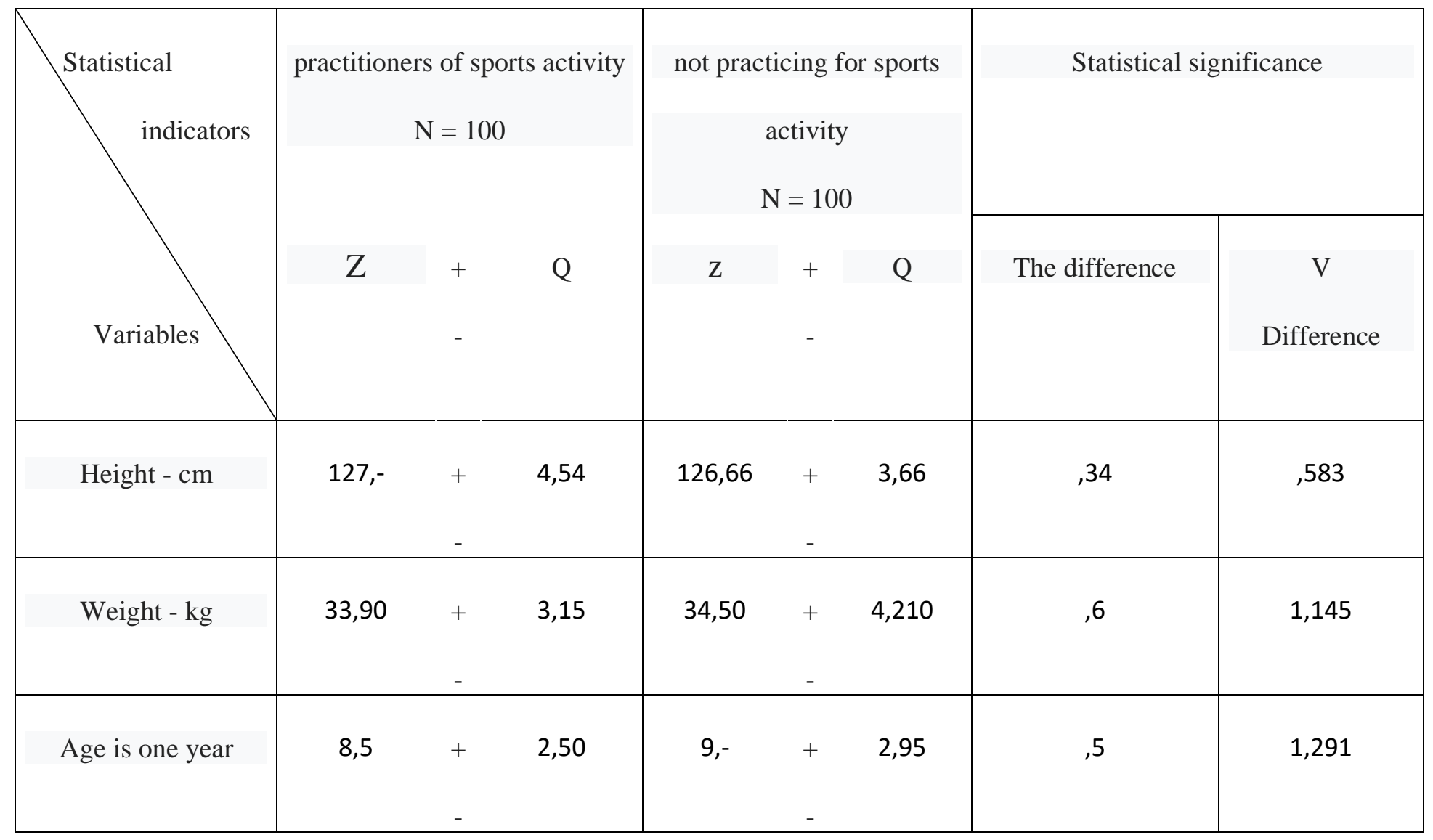

Table (1) shows the equivalence and homogeneity of the research sample from practitioners and nonpractitioners of sports activity in the basic variables, height, weight and age

\section{Statistical treatments:}

\# Arithmetic mean .

\# standard deviation .

\# Test (v). 


\section{Presenting and discussing the results:}

\section{Table (2)}

The arithmetic mean, the standard deviation, and the calculated value $(\mathrm{t})$ of aggressive behavior toward the self for practitioners and non-practitioners.

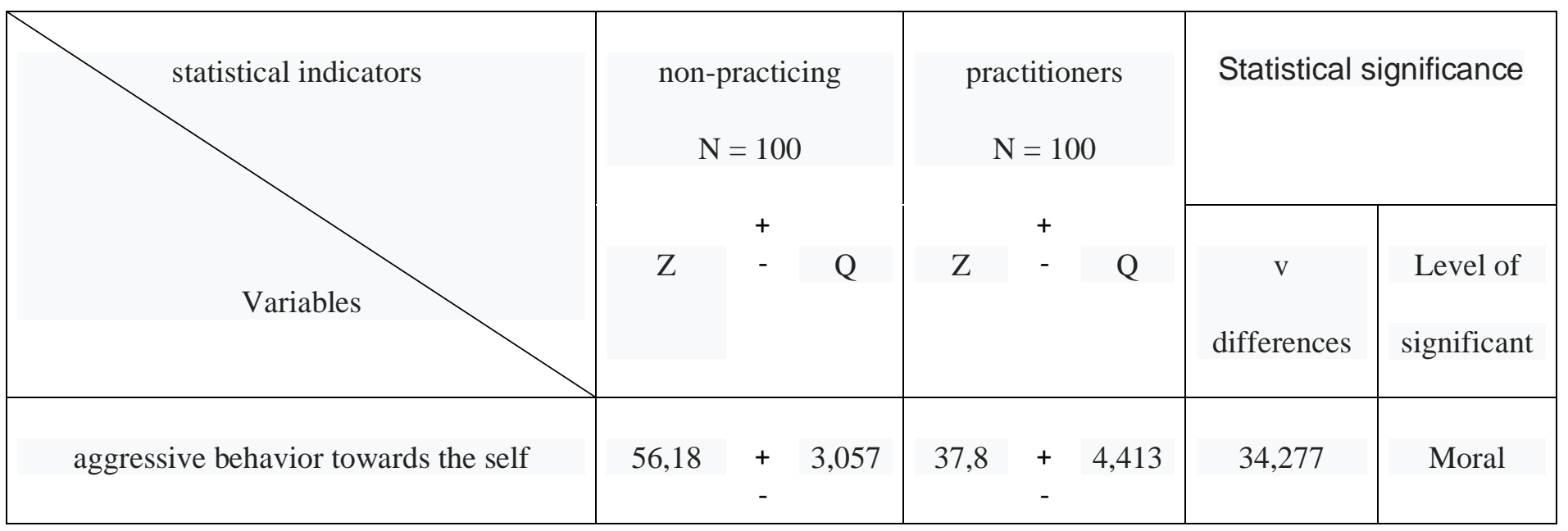

The value of the $(T)$ tabular at the level of significance $(05$,$) equals 1,98$

Table (2) shows the arithmetic mean, the standard deviation, and the calculated value of $\mathrm{T}$ between practitioners and non-practitioners of sports activity, which shows the superiority of practitioners over non-practitioners in aggressive behavior toward the self and which indicates a decrease in the rate and level of aggressive behavior toward the self as a result of the exercise of sports activity and this is what achieves the first hypothesis and agrees With the study of (Ali Hassan Al-Khafaji 2011) and

(Hassan Nassar 2017). 
Table (3)

Arithmetic mean, standard deviation, and the calculated $(T)$ value of aggressive behavior towards others for practitioners and non-practitioners of athletic activity

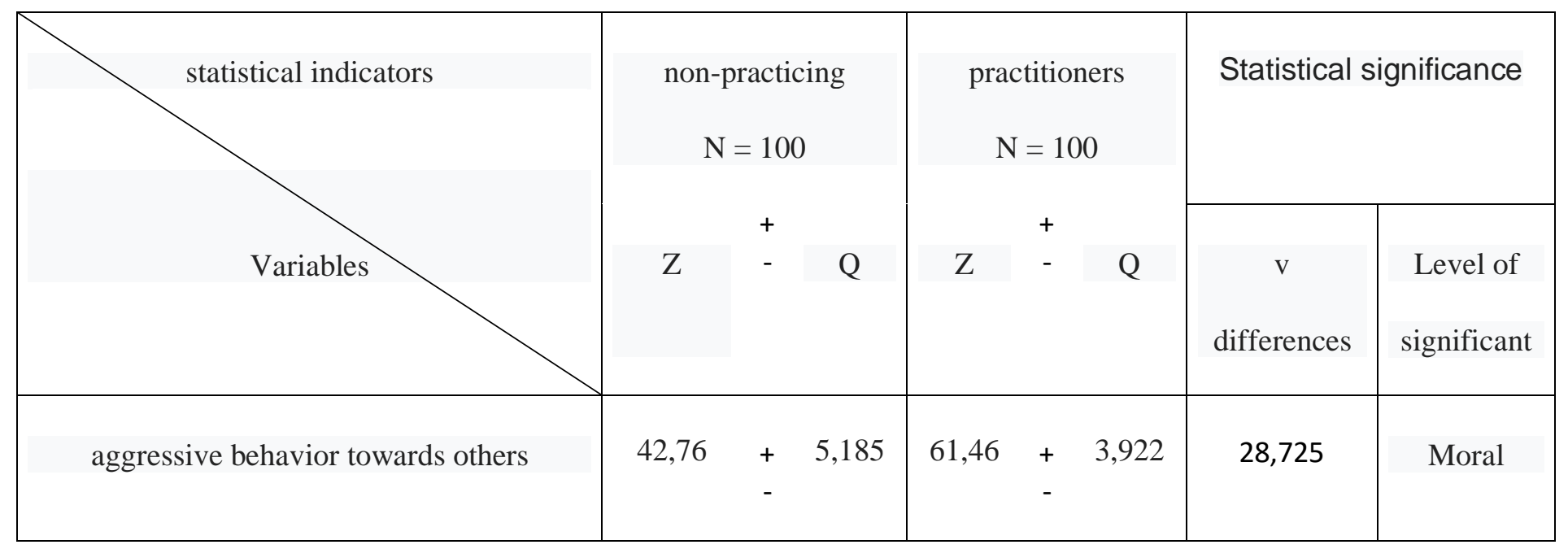

The tabular value of $(T)$ at the significance level $(05$,$) is 1.98$

Table (3) shows the arithmetic mean, the standard deviation, and the calculated value of $\mathrm{T}$ between practitioners and non-practitioners of sports activity, which shows the superiority of practitioners over non-practitioners in aggressive behavior towards others, which indicates a decrease in the average level of aggressive behavior towards others as a result of the exercise of sports activity in line with the study of Mori, Kevin and others. This is what meets Moore, Keven- Jet al 2004.

\section{Table (4)}

Arithmetic mean, standard deviation, and the calculated value $(t)$ of aggressive behavior toward property for both practitioners and non-athletes.

\begin{tabular}{|c|c|c|c|c|c|c|c|c|}
\hline statistical indicators & \multicolumn{3}{|c|}{$\begin{array}{l}\text { non-practicing } \\
\qquad \mathrm{N}=100\end{array}$} & \multicolumn{3}{|c|}{$\begin{array}{l}\text { practitioners } \\
\qquad \mathrm{N}=100\end{array}$} & \multicolumn{2}{|c|}{ Statistical significance } \\
\hline Variables & $\mathrm{Z}$ & $\begin{array}{l}+ \\
-\end{array}$ & Q & $\mathrm{Z}$ & $\begin{array}{l}+ \\
-\end{array}$ & Q & $\begin{array}{c}\mathrm{v} \\
\text { differences }\end{array}$ & $\begin{array}{l}\text { Level of } \\
\text { significant }\end{array}$ \\
\hline aggressive behavior toward property & 35,14 & + & 6,947 & 55,07 & $\begin{array}{l}+ \\
-\end{array}$ & 5,664 & 22,218 & Moral \\
\hline
\end{tabular}


The value of the $(T)$ tabular at the level of significance $(05$,$) equals 1,98$.

Table (4) shows the arithmetic mean, the standard deviation, and the calculated value of (T) between practitioners and non-practitioners in aggressive behavior toward properties as a result of exercising activity.

Athlete, as the programs affect positively the behavior and also modify the aggressive behavior

Nugent-William et al 2005 Nugent-William et al

And also to know the effectiveness of the change in aggressive behavior in children as stated in a study Hukanen et al 2005, Heikenen et al.

\section{Table (5)}

Arithmetic mean, standard deviation, and the calculated $(T)$ value for the overall aggressive behavior of practitioners and non-practitioners of athletic activity.

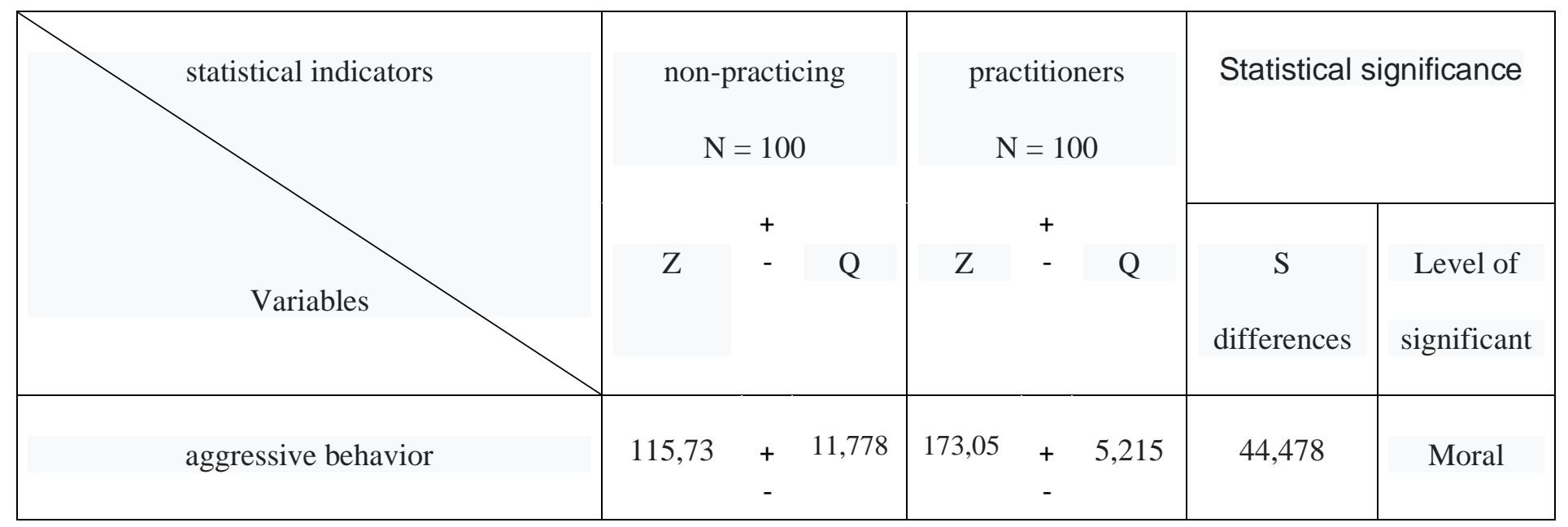

The tabular $(T)$ value at the significance level $(05)$ is 1.95

Table (5) shows the arithmetic mean, the standard deviation, and the calculated value of the aggressive behavior of the practitioners and non-practitioners of the sports activity, which showed the superiority of the practitioners over the non-practitioners of the athletic activity and the decrease in the aggressiveness intensity as a result of the exercise of the sports activity outside the official working hours of the school and this is what achieves the fourth hypothesis and the overall excitement of the research as Practicing sports activity has a positive effect in reducing the severity of aggressive behavior and it is the only outlet for investing energy and spending it for what it benefits.

This indicates the positive effect of sports activity on aggressive behavior and proves the validity of the research hypotheses. These results are consistent with the results of the study (Iqbal Lifta 2012) and the study (Abu Masjid Abdul Qadir 2001 AD) and the study (Abu Namla Sufyan 2001 AD) and the study (Issa Al-Hadi and others 2019) and also the study (Ahmed Abdul Jawad 2006 AD). 


\section{Conclusions:}

In light of the results reached by the researcher after applying the measure of aggressive behavior in its three dimensions (aggression towards self, aggression towards others, aggression towards properties) to know its role and its impact on a group of students from the first primary stage of practicing sports activity and the second non-practicing sports activity, the researcher concluded what Follows:

\# The practice of sports activity has a positive effect on the degree of aggression towards the self for the benefit of a group of sports activity practitioners.

\#\# The practice of sports activity has a positive impact on the degree of aggression towards others in favor of a group of sports activity practitioners.

\#\#\# The exercise of physical activity has a positive effect on aggression towards property for the benefit of a group of athletic activity.

\#\#\#\# Exercising in sports has a positive effect on aggressive behavior as a whole for the benefit of a group of athletic activity.

\section{Recommendations:}

In light of the research findings, the researcher recommends the following:

\# The necessity of practicing sports activity regularly due to its positive impact on the average level of aggressive behavior.

\#\# Urging students to practice sports (sports) outside the official school hours because of its positive impact on the average level of aggressive behavior.

\#\#\# The necessity of making primary schools a (breathing room) for sports activity after the end of the official working hours. 


\section{References:}

\section{First: Arab references:}

$$
\begin{aligned}
& \text { 1- ابو غلة سفيان : الوكيات العدوان أثناء حصة التربية البدنية والرياضية ، رسالة } \\
& \text { ماجستير ، العر اق، 2001م. } \\
& \text { 2- إقبال عمار لفتة : تأثثير ممارسة التربية البدنية والرياضية على خفض السلوك } \\
& \text { العدو اني لدى طلاب المرحلة الماوسطة بأعمار(12-15) سنه } \\
& \text { مجلة در اسات نربوية ، العراق. العدد 19، 2012م. } \\
& \text { 3- بوسجد عبد القادر : استخدام اللعب الحركي لخفض السلوك العدواني لدى الأطفال } \\
& \text { بأعمار 5-6 سنوات ، رسالة ماجستير ، العراق2001 . } \\
& \text { 4- حسين أحمد الثافعي : مبادئ البحث العلمي في التربية البدنية والرياضية ، منشأه }
\end{aligned}
$$

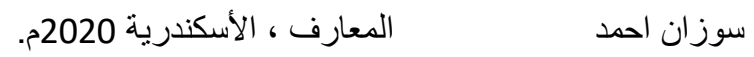

$$
\begin{aligned}
& \text { 5- حن عبد الفتاح نصار : فاعلية برنامج تدريبي بإستخدام الأنشطة الحركية للحد من } \\
& \text { السلوك العدو اني لدى عينة من أطفال التوحد ، بحث رسالة } \\
& \text { ماجستير ، كلية التربية ،جامعة الأزهر ،غزة 2017م. } \\
& \text { 6- علي حسن الخفاجي : تأثير منهج تعليمي باللعب لتتمية التو اصل اللغوي } \\
& \text { المصابين بطيف التوحد ، مجلة كلية التربية الرياضية ، جامعة } \\
& \text { بغداد ، المجلة 23، العدد (2) للأطفال.2011م. }
\end{aligned}
$$

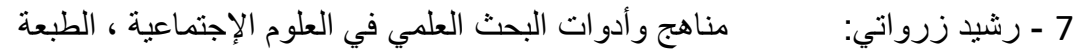

$$
\begin{aligned}
& \text { الأولى ، عين جليلة ، الجز ائر } 2007 \text { م. }
\end{aligned}
$$

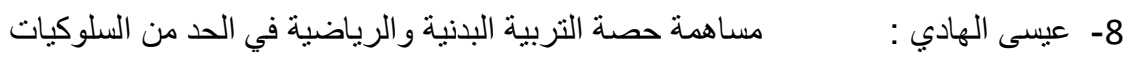

$$
\begin{aligned}
& \text { لارين سليمان العدو انية لدى تلاميذ الستة الرابعة متوسط ، مجلة علوم التربية } \\
& \text { رامي عز الدين الرياضية المجلد } 12 \text { ، جامعة بابل ،العدد(1) } 2019 \text { م. }
\end{aligned}
$$

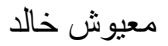

$$
\begin{aligned}
& \text { 9- أحمد عبد الجواد : مدى فعالية برنامج لتعديل السلوك العدو اني لاى الأطفال من نز لاء المؤسسات ، } \\
& \text { فهمي تعيلب رسالة ماجستير ، كلية الأداب قسم علم نفس جامعة الزقازيق .2006م. } \\
& \text { 10- سامي محمد زيدان : فاعلية الذات ودور الجنس لدى التلاميذ الأيتام والعاديين في } \\
& \text { مرحلة الطفولة المتأخرة ، رسالة ماجستير ، كلية التربية ، جامعة المنصورة، 2000م. }
\end{aligned}
$$




$$
\begin{aligned}
& \text { 11- حن مصطفى: المناخ الأسري وشخصية الأبناء ، الطبعة الأولى ، القاهرة ، دار } \\
& \text { عبد المعطي السحاب ، 2004م. } \\
& \text { 12- طاطم كريمة: فعالية العلاج باللعب في تخفيف السلوك العدو اني عند الطفل من } \\
& \text { سن 5-8 سنوات ، مذكرة تخرج لنيل شهادة الماجستير ـ قسم } \\
& \text { العلوم الإجتماعية ـ شعبة علم نفس ـ وزارة التعليم العالي } \\
& \text { و البحث العلمي ـ الجمهورية الجز ائرية الثعبية 2015م. } \\
& \text { 13- إبر اهيم أحمد عطية : مدى فاعلية برنامج مقترح لتعديل السلوك العدو اني لاى الأطفال } \\
& \text { ضعاف السمع ، رسالة الدكتور اه معهد الدر اسات العليا للطفولة ، } \\
& \text { جامعة عين شمس ،2002م. } \\
& \text { 14- حسين أحمد الثافعي : مبادئ البحث العلمي في التربية البدنبة و الرياضية ، منشأة } \\
& \text { سوزان أحمد 2002م. المعارف .الإسكندرية } \\
& \text { 15- فاطمة عوض صابر : أسس البحث العلمي .الطبعة الأولى ـ مكتبة ومطبعة الأشعاع } \\
& \text { ميرفت علي خفاجة العلمية ـ الأسكندرية 2002م } \\
& \text { 16- رشيد زرواتي : مناهج و أدوات البحث العلمي في العلوم الإجتماعية .الطبعة } \\
& \text { الأولى عين جليلة . الجزائر 2007م. }
\end{aligned}
$$

Second: Foreign references:

- 17 -Hukkanen, -Raija; Sourander, Andre, Bergroth: Followup of children and adolescentsin residential care in children's homes, social welfarectr of the city of turku Finland, Journal -ofPsychiatry; Vol. 53 (3): $\quad$ (2005) P 185-189.

18- Nugent, William- R; Bruley, - Charlene; Allen, - Patricia: The effects of aggression replacement training on antisocial behavior in arun away shelter, u Tennessee, coll of social work, Journal, Nov. Vol 8 (6): $637-656$ (2005)

19 - Moore, - Kevin - J; Shannon, - Kelly - K: The development of superstitious beliefs in the effectiveness of treatment of anger: Evidence for the importance of experimental program evaluation in applied settings. Oregon social learning ctr, Eugene, us. Apr; Vol 8 (2): 147 - 161. (2004) 


\section{Research Summary}

The role of sports activity in the level of aggressive behavior of primary school pupils

* Hadeer Emad Al-Din Nofal Ahmad

**Sakina Mohamed Nasr

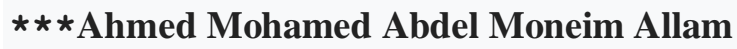

This research aims to identify the role of sports activity in reducing the level of aggressive behavior for primary school pupils by measuring aggressive behavior with its three axes (towards the self - towards others - towards the properties) on a sample of primary school pupils from the age of (6-9) years And a group of practitioners of sports activity consisting of 100 pupils and another group of non-practitioners of sports activity consisted of 100 pupils and the results resulted in the superiority of pupils practicing sports activity in the level of aggression and the study confirmed that sports activity contributes significantly to reducing the unit level of aggression and the researcher concluded that sports activity should be included It included the daily program for pupils and made the school a sports edifice outside the official working hours.

* Researcher at the Ph.D. stage, Department of Fundamentals of Physical Education, Faculty of Physical Education for Boys, Alexandria University

** Professor of Mathematical Psychology, Department of Fundamentals of Physical Education, Faculty of Physical Education, Alexandria University *** Assistant Professor, Department of Fundamentals of Physical Education, Faculty of Physical Education for Boys, Alexandria University. 


\section{ملخص البحث}

دور النشاط الرياضي في مستوى السلوك العدواني لتلاميذ المرحلة الابتدائية

هدير عماد الدين نوفل أحمد* - مدا"

* * * * * * * * محمد نصر

( أحمد محمد عبد المنعم علام

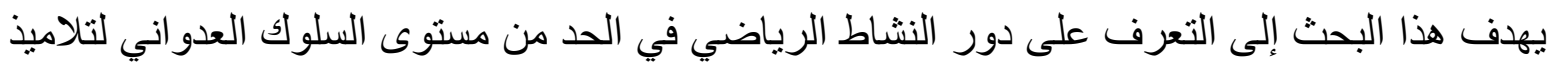

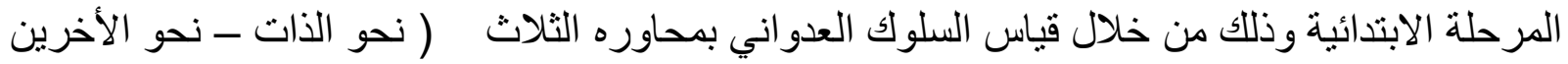

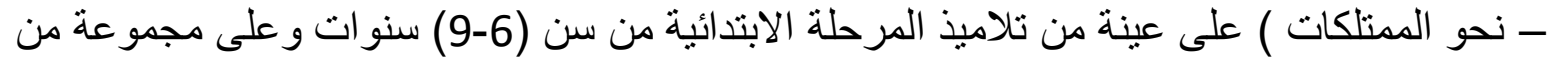

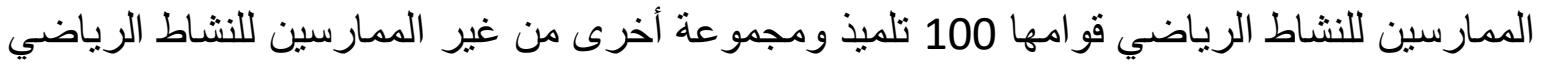

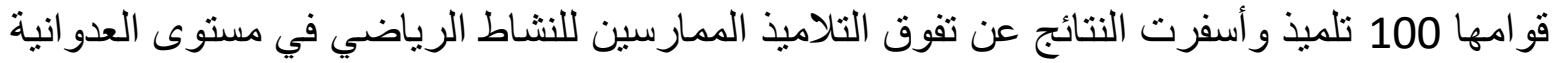

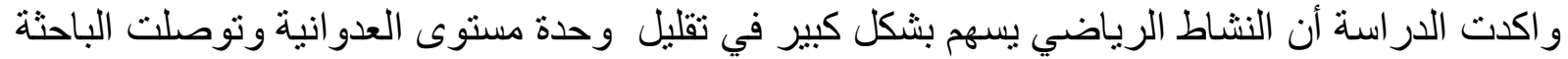

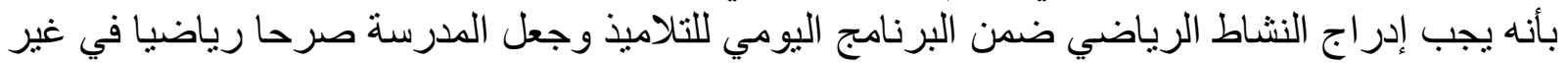
أوقات العمل الرسمي .

* باحثة في مرحلة الدكتور اه، قسم أصول التربية الرياضية ،بكلية التربية الرياضية للبنين جامعة الإسكندرية في ماحسة ** أستاذ علم النفس الرياضي بقسم أصول التربية الرياضية ، بكلية التربية الرياضية جامعة الإسكندرية.

****أستاذ مساعد بقسم أصول التربية الرياضية ، كلية التربية الرياضية للبنين ، جامعة الأسكندرية. 
